important discoveries of the expedition. Its dimensions are approximately 30 yards by 25 yards; and its walls aro exceptionally heavy, the outer walls being more than eight feet thick. They are buttressed with rough blocks of limestone and basalt. Tho temple dates from about 3000 B.C. and is thus the oldest shrine yet discovered in eastern Syria. Its architectural relationship to archaic temples at Warka, about eight hundred miles down tho Euplurates from Brak, points to cultural contacts between north-east Syria and Sumer at this early date. A striking feature of the plan of the temple is a central shrine, three times as long as it is wide, with a pedestal for the presiding god against the end wall.

THE adornment of the temple would appear to have been remarkable. A magnificent frieze consisted of three separate panels on the three faces of the pedestal in the sanctuary. Each of these was three feet in length and eight inches in breadth, and was composed of outer bands of heavy gold foil encasing blue limestone, white marble, and green corrugated shale. The panels were fastened to a wooden background with copper holdfasts, while the gold borders were held down by gold-headed nails with silver stems. No panels of this kind have previously been discovered. Ono of them has been allocated to the British Museum. Fragments of fluted copper panelling, which had adorned the walls, have been discovered; while on the south side the wall was embellished with a mosaic of clay cones painted in bright colours, and surmounted by large stone rosettes with alternate petals of white marble and dark green shale and a central corolla of red limestone. In the material of the mud-brick platform on which the temple stood, many thousands of objects wero found. These include many beautifully carved amulets-models of lions, rams, bears, monkeys and rultures in serpentine and bone. A number of human heads in alabaster are said to be landmarks in the history of sculpture. A summary of the report appeared in The Times of October 14.

\section{Juvenile Delinquency}

Is a discussion on juvenile delinquency before tho Royal Statistical Society on April 18 which has now appeared (J. Roy. Statist. Soc:, 102, 381 ; 1939), Dr. Rhodes concludes that juvenile crime appears to be part of a major problem, including adult crime, which involves social and economic considerations. More exact information regarding the age-constitution of local populations is required to gauge properly the differences between the incidence of juvenile crime in different parts of the country. In considering changes with time, we must take account of changing environment if we are to deduce anything from the facts of recorded crime regarding changes in the naughtiness of the juvenile population. Mr. C. P. Hill agreed that juvenilo delinquency was linked both with density of population and with unemployment, but considered there were so many other unknown variables to be taken into account that no accurate forecast was possible as to the probable future course of juvenile delinquency from the data available. Mr. J. H. Bagot, from Liverpool experience, stressed the wastage in probation and education offices and police departments through the non-use of statistics, and concluded that tho vast proportion of the delinquents were drawn from one section of the population, and, within that section, from a defective group, either from the point of view of family or overcrowding.

\section{Alcohol and Crime}

IN an important paper on the problem of alcohol and drug addiction in relation to crime, published in the October issue of the British Joumal of Inebriety, Ir. WV. Norwood East, formerly H.MI. Commissioner of Prisons, discusses the relation of parental alcoholism and drug addiction to crime, alcoholism in the individual as a causo of crime, the medical and legal aspects of alcoholic crime, and the treatment of criminal alcoholics and drug addicts. Ho illustrates the insignificant part played by drug addiction as a cause of crime, at least in Great Britain, by the fact that in 1937, when the number of drug addicts known to tho central authority was only 620 , not more than 31 persons wero dealt with under the Probation of Offenders Act, or fined or imprisoned for offences against the Dangerous Drugs Act. Dr. East further points out that while every practical criminologist will attach some importance to the association of alcoholism and crime, it is easy to over-emphasize the connexion, and in support of this contention brings forward statistics from various prisons showing that familial or individunl alcoholism is a much loss frequent cause of crime than was formerly supposed. While allowing that the general medical treatment of alcoholism and drug addiction may bo supplemented by psychotherapy in suitable cases, Dr. East asserts that this method is apt to be disappointing, and that he does not know of any impressive series of figures illustrating the success of such treatment.

\section{Future of Welding}

Ir is now known that the substitution of fabrication for casting is very advantageous to heavymachine makers in a number of ways, mainly because it obviates the necessity of pattern-making. The time that would otherwise be lost in the foundry is considerable, especially when new patterns have to be evolved. In a leader on welding in the Electrical Review of September 29, it is stated that many electrical and allied manufacturers are now using welding on a fairly large scale. Some of them go so far as to design and make their own welding equipment. There are on a conservative estimate about forty manufacturers of electric welding machines in Great Britain and there are nearly as many suppliers of rectifiers for welding and thermionic valve control devices. Besides, there are one or two factories which make holding frames for rotating or otherwise manipulating the welding work being done. It is probable that not more than about a quarter of the known applications of welding are utilized in industry. The large amount of research being done is shown 
in the second progress report of the Institute of Welding. Further evidence is given of the increased applications by the issue of official regulations and specifications for welded steelwork by national bodies in many countries. Some manufacturers think that tho welding industry may ultimately employ as much capital and labour as the steel industry now does. Such considerations apply equally to shipyards. and remembering the inherent water, oil and gas tightness of welded vessels, the rate of advance in the uso of welding in shipyards will doubtless advance more rapidly in the future. The progressive widening of applications is producing fresh problems. Large. scale operations indicate the desirability of carrying out as much as possible of the actual welding in specially dovised workshops rather than at the ship. building berth. This requirement will sometimes entail the re-design of component sections to render them more transportable and also the provision of suitable and adequate manipulative and adequate lifting equipment.

\section{Johannesburg Municipal Bus and Tram Sheds}

THE all-welded structure of the new municipal bus and tram sheds at Johannesburg is claimed to cover an area greater than that of any other wolded structure in South Africa. In Electric Welding of August, it is stated that, excluding an office block of reinforced concrete, the building has a frontage of 465 feet and an area of approximately 186,000 square feet. The outer walls are of concrete but all the interior walls are steel-framed. The floor is of con. crete throughout. To give unobstructed floor space, the number of columns was cut down to a minimum. Tho largest of the girders span 90 feet and are 12 feet deep. They were dispatched by road from the company's workshops at Benoni, whero all the steelwork was fabricated. To allow of transportation through Johannesburg, they were split into halves, tho halves being welded together at the site and the girders lifted in one pieco. A striking feature of the design is the absence of gusset plates and the lightness of all the sections employed. The entiro framework is welded, including even the site connexions. The saw-toothed type of roof employed produces oxcellent internal lighting. The percentage of windows to floor spaco is about thirty. The lamps provided are of the mercury vapour type. Botween 500 and 600 tons of steel were used in the erection of the sheds, the greater portion of this steelwork being produced in South Africa.

\section{Electric Lighting in a Modern Store}

IN Welwyn Garden City, Herts, an entirely now building now houses tho Welwyn Stores; a closcription of the building is given in the Electrical Review of October 13. The Velwyn Electricity Supply Co. built and equipped a new sub-station near the site to meet the required demand. The G.E.C. Co., Ltd., installed the whole of the lighting and fittings for 336 combined tungsten and Osira lamps. The outside illumination consists of four large neon signs. The shop fronts have artificial stone piers, marble risers and a painted wooden facia and cornice in which is set a line of fluorescent tubing running round three sides of the building. About 900 feet of 'Clora' coated tubing has been used for this purpose. The store itself comprises ground floor and part of the first floor. Under an artificial daylight effect achioved by 'T.O.T.' units, the natural waxpolished oak counters, stock fittings and panelling show up well. During the daytime, the daylight entering the ground floor through 'glass-crete' rooflights from the staircaso blends with the artificial illumination, all strong contrasts being eliminated. Each lighting unit consists of ono 80-watt 'Osira' fluorescent type discharge lamp and threo 150-watt tungsten lamps enclosed in opal sphere pendants 18.in. in diameter. All the main selling floors have this typo of lighting. The food hall is a separate section on the ground floor. There are 1,400 feet of fluorescent tubing, arranged round the ceiling in three parallel rows-ono red tube and two bluoand the effect of this diffused brilliance is enhanced by the green and white chequered flooring, the tiled walls and counter fronts, and other modern fittings. Light signalling by pro-arranged combinations of four different colours is used throughout the storo for attracting the attention of managers or other persons.

\section{Soil Science at Adelaide}

THE Winter School in Soil Science held during August 14-23 at the Waite Agricultural Research Institute, Adelaide, was a signal success. It was sponsored by the Council for Scientific and Industrial Research and the University of Adelaide and met under the chairmanship of Prof. J. A. Prescott. Sixty members attended, all directly engaged in work on soils, and representative of universities, State departments of agriculture and of forestry, water supply commissions, Government chemical labora. tories and other interests. Papers were presented on classification, physical composition, colour, water relations, acidity and lime requirement of soils; methods of soil surveying and utilization of soil maps and data; spectrochemical and polarographic methods of analysis; methods for determination of soil carbon, soil reaction and soluble salts; the erosion problem in pastoral areas; and other topics. Numorous demonstrations were arranged. As a result of the School, soil investigators throughout tho Commonwealth will in future be working in more intimate association and along more uniform lines.

\section{Rare Medical Books}

ON the occasion of the seventieth birthday earlier this year of the late Prof. Harvey Cushing, Schuman's of New York brought out, under the title of "Seventy Noteworthy Medical Rarities", an illustrated and annotated catalogue to which are prefixed a portrait of Dr. Cushing, taken about forty years ago, and an appreciation of the eminent surgeon and bibliophile by Dr. Lawrence Reynolds. Among the notable works listed in the 